\title{
Chapter 21 \\ Nutrition-Sensitive Value Chain \\ Development in a Changing Climate
}

\author{
Summer Allen and Alan de Brauw
}

\subsection{Introduction}

Food security has improved over the past quarter century in developing countries, with the number of undernourished people declining from 900 million in 2000 to 815 million in 2017 (FAO 2017). Yet while a larger proportion of the world's population can now access enough food in terms of caloric requirements, it is not necessarily nutritious. The 2016 Global Nutrition Report states that micronutrient deficiency remains stubbornly high, with obesity rates increasing rapidly in lowand middle-income countries (IFPRI 2016). For example, wasting (low weight for height, a sign of undernutrition) affected 52 million children under 5 in 2016, yet 41 million children were overweight the same year (FAO 2017).

In sub-Saharan Africa and South Asia, regions which rank highest in malnutrition rates, climate change poses a severe threat to food security; changes in temperature, precipitation patterns and disease environments are expected to reduce yields by levels as high as $2 \%$ per decade (GLOPAN 2015). Whilst heat and water stress will increase the incidence of pests and diseases, higher temperatures will also increase spoilage of fresh, nutritious foods, and climate events such as flooding will prevent their transport to market (Vermeulen et al. 2012). Climate change can also exacerbate nutritional deficiencies - increased $\mathrm{CO}_{2}$ concentrations reduce the nutritional quality of crops, such as the protein content of grain crops and soybeans (Myers et al. 2017; Taub et al. 2008).

Most studies focus on the effects of climate change on agricultural productivity levels, but few have analysed the impact of climate change on household nutrition (e.g., Kabubo-Mariara et al. 2016; Springmann et al. 2016). For example it is estimated that globally, reduced fruit and vegetable consumption (caused by reduced

\footnotetext{
S. Allen $(\bowtie) \cdot$ A. de Brauw

Markets, Trade and Institutions Division, International Food Policy Research Institute

(IFPRI), Washington, DC, USA

e-mail: s.allen@cgiar.org; a.debrauw@cgiar.org
} 


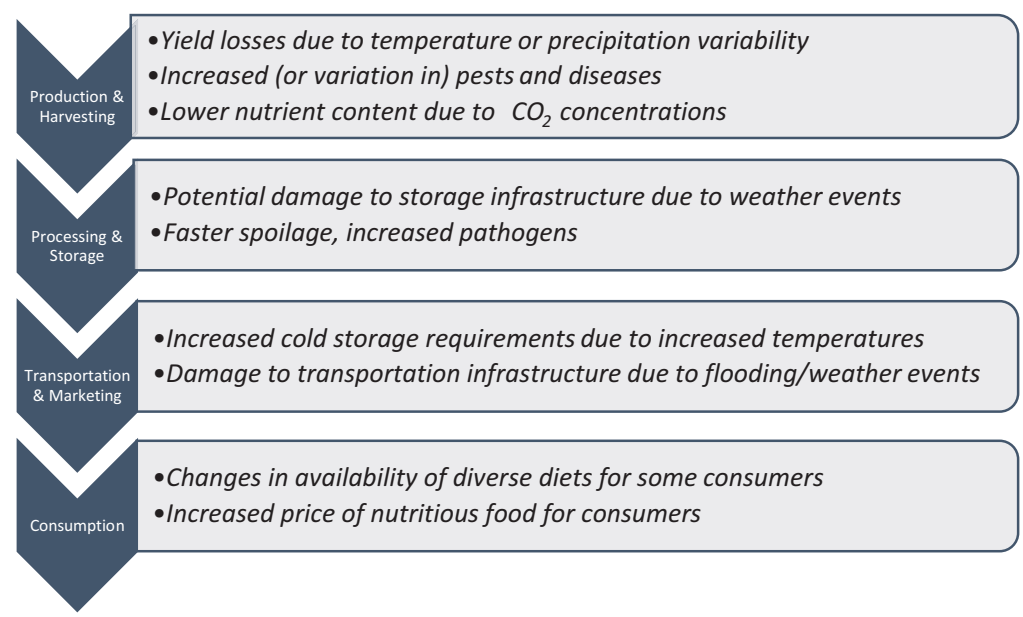

Fig. 21.1 Potential climate-related impacts to food value chains

crop availability and changes in consumption patterns) will result in 534,000 deaths (Springmann et al. 2016). Another study estimates that the number of malnourished children in developing countries is likely to increase by $8.8-10 \%$ due to climate change (Nelson et al. 2010).

By definition, food value chains include all actors and activities from producer to consumer, including: inputs into production, crop production, storage and processing, distribution and transportation, food retail and labeling, and consumption. The vulnerability of value chain activities to climate change could make production more expensive. Other factors could also affect costs, such as changes in energy or agricultural policies (Fig. 21.1). For example, rising temperatures and variable precipitation patterns will impact growing seasons, locations and water and nutrient demand, whilst also risking food safety, making storage and transportation even more critical (Fanzo et al. 2017).

Globally, agriculture and food systems need to adapt to meet the challenges of climate change if they are to support the diet of the growing global population. One promising option is the development of more nutrition-sensitive value chains that increase access to nutritious foods for local markets (e.g., Hawkes and Ruel 2012; Gelli et al. 2015). This approach relies on crop varieties that are tolerant to drought and heat, commodities with increased nutrient content, and reduced food losses.

This chapter provides a brief overview and examples of nutrition-sensitive value chains, and the research and findings thus far regarding how they can improve nutrition at the household level in Africa. The policy efforts supporting nutrition-focused agricultural practices in a changing climate will also be discussed. 


\subsection{Nutrition-Sensitive Value Chains}

Achieving the second Sustainable Development Goal (to end hunger, achieve food security and improved nutrition, and promote sustainable agriculture) is challenging in a changing climate. Under most conditions, dietary choice does not align with what is optimal nutritionally (Allen and de Brauw 2017). There are, however, ways to improve the nutritional intake of consumers. Nutrition sensitive value chain interventions are a class of interventions that take place through a range of value chain actors to ensure more nutritious products reach consumers. Relative prices can shift either through improvements in the value chain or through regulation. Likewise, marketing campaigns and improved labelling can persuade the consumer to purchase more nutritious foods.

Decisions made on the supply side, for example regarding which foods to produce or with whom to trade, largely depend on the expected profit, which limits the nutritional composition of foods in the value chain. The nutrition-related or environmental consequences of value chain activity are rarely monetised. Producers are unlikely to shift production to more nutritious or environmentally sustainable foods if they will not result in increased profit. Previous research on nutrition-sensitive value chains, therefore looked for ways to ensure profitability, such as temperaturecontrolled supply chains for perishable foods, contracts that support the production of vegetables, and increased subsidies for infrastructure and inputs (Allen et al. 2016; Chege et al. 2015; Stifel and Minten 2017).

To create sustainable, climate-smart value chains consideration of synergies and trade-offs among economic, environmental and social objectives, including nutrition and health may be required (FAO 2013). For example animal source foods (meat, milk, eggs) are nutrient-dense, but producing them is both land and water intensive (Marlow et al. 2009). As the climate changes, these social, environmental, and economic trade-offs will shift with relative prices and the profitability of specific activities will change. Examples of this include the effect of variations in monsoon timing and strength in India (upon which both agriculture and energy depend), and the effects of biofuel policies in countries such as Ethiopia, that can lead to higher food prices and land use changes when compared to policies focused on agriculture and food security (Lobell et al. 2014).

Figure 21.2 illustrates the complex relationships that must be considered in nutrition-sensitive value chains: a delicate balance of economic (profit), social (including nutrition), and environmental impacts, including greenhouse gas emissions (figure adapted from FAO 2013). Though many of these social and environmental impacts are not monetised, pressure on resources (for example, through drought, floods and changes in soil productivity) and changes in consumer demand (for example, for products such as palm oil or animal source foods) can affect profitability and promote unsustainable production decisions. 


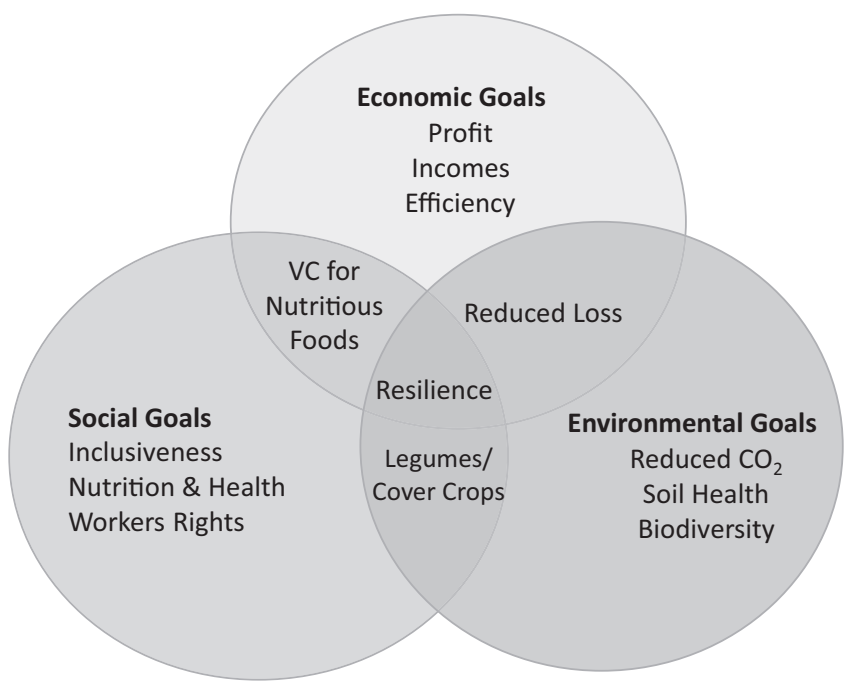

Fig. 21.2 Trade-offs and synergies for sustainable food chain development. (Source: Authors' Adaptation from FAO 2013)

\subsection{Value Chains for Nutritious Foods: Lessons from the Field}

Increasing the availability of nutritious foods is necessary to deal with substantial micronutrient malnutrition. In 2014, 32\% of children below the age of 5 in subSaharan Africa were stunted (IFPRI 2016). Unfortunately, household-based interventions to improve the diet are often expensive (e.g., de Brauw et al. 2015). Such interventions are also complex. In Ethiopia, for example, increasing knowledge about nutrition was successful in improving dietary diversity, but only when households had sufficient market access (Hirvonen et al. 2017). Despite the challenges, value chain interventions have the potential to be cost-effective as they involve the private sector and, if successfully expanded, can reach a much larger set of beneficiaries than interventions focusing on individual households.

One intervention which would increase food security and diet diversity and that has potential for upscaling is the distribution, through input dealers, of nutritious crops that are more resilient to climate shocks. Beans are nutritious, but their productivity gains have lagged behind grain crops (Joshi and Rao 2017). In Malawi, the International Center for Tropical Agriculture (CIAT) and the Pan-Africa Bean Research Alliance (PABRA) have collaborated to study access to improved bean varieties. Though there is evidence of higher yields and dietary diversity for those who adopt the improved varieties, their initial use is associated with access to extension and mobile phones (Katungi et al. 2017).

Given the positive relationship between production diversity and dietary diversity shown in subsistence-oriented contexts, crop diversification could meet the dual needs for a more resilient crop mix (in the case of pests, disease, or extreme weather) and a 
more diverse diet at the household level. However, this relationship is not always positive. Once strong access to markets or increased technology adoption in agriculture is attained with concurrent increases in agricultural income, the relationship between production diversity and dietary diversity does not appear to be as strong (Koppmair, Kassie, and Qaim 2016). Farmers that are able to specialise do so because they both have higher incomes and they are able to mitigate the risk of specialisation.

Local supply chains that support more diverse diets can address these challenges. For example, in several countries homegrown school feeding programs that source school food from local producers have been implemented (WFP 2017). Recent work in Malawi has focused on testing whether such programs, when combined with behavior change communication (to improve nutrition, support local agriculture, and improve attendance at schools), can be effective in addressing malnutrition. The results are currently being finalised, but there is already evidence that these types of interventions can lead to improved dietary intake in preschool children and growth in their younger siblings (Gelli et al. 2017).

Finally, one of the most promising initiatives to increase the content of micronutrients in diets is biofortification, which involves breeding staple crops, including sweet potato, maize, beans and cassava, for higher micronutrient levels (Bouis et al. 2011). HarvestPlus has released biofortified crops and is supporting their inclusion into value chains and the market system in the Democratic Republic of Congo, Rwanda, Nigeria, Uganda and Zambia. For example, they are working with food processors to develop and market products using yellow cassava fortified with Vitamin A in Nigeria, and orange maize in Zambia (HarvestPlus 2017). Randomised control trials have demonstrated that biofortification can be effective in reducing the prevalence of inadequate micronutrient intake (Hotz et al. 2012a, b).

\subsection{Nutrition-Sensitive Value Chains in a Changing Climate}

In 2017 the World Economic Forum highlighted the need for inclusive, sustainable and efficient food systems that deliver nutritious food. Climate change significantly impacts malnutrition, both directly, through heat stress and water constraints, and indirectly, through loss in production. These impacts could be as large as changes in other socioeconomic indicators such as access to electricity and educational attainment (Davenport et al. 2017). The effect on stunting, however, could be partially mitigated by investments in education and electricity (Davenport et al. 2017). To build food systems that are resilient to climate change, it is critical that limited resources are used efficiently and losses reduced across the value chain (FAO 2013).

At the farm level there are opportunities for agroforestry to promote nutritious crops while ensuring more sustainable production in terms of soil health and carbon sequestration. The Initiative for the Adaptation of African Agriculture to Climate Change (AAA Initiative) notes opportunities for more integrated management of pastoral and forest systems that, in turn, can improve management of limited resources; agroforestry in particular offers the opportunity for producers to diversify their production (and income), maintain soil fertility and water resources, and provide 
carbon sequestration (AAA Initiative 2017). In addition to maintaining soil health and increasing pollination, forests also provide nutritious food (fruits, berries, mushrooms), cooking fuel and income opportunities (through the sale of forest products). In addition to maintaining soil health and increasing pollination, forests also provide nutritious food (fruits, berries, mushrooms), cooking fuel and income opportunities (through the sale of forest products); in southern Ethiopia proximity to a forest increased dietary diversity due to the increase in feed for livestock and resulting organic fertilizer for home gardens (Baudron et al. 2017).

It is critical that loss at the farm level is reduced by developing nutritious, resilient crop varieties that can tolerate climate variability. For example, researchers at the World Vegetable Center evaluated heat-tolerant and disease-resistant tomato varieties in Tanzania and found the rate of return to seed improvement to be as high as that reported for some staple crops (Schreinemachers et al. 2017). In the same region, access to improved pigeonpea varieties also increased income returns for farmers (Shiferaw et al. 2008).

Ultimately, to take full advantage, resilience at the farm level should be pursued together with activities such as increasing soil organic carbon and diversity of production and trade (FAO 2013). On farm, activities that promote nutrition-sensitive agriculture can improve soil organic carbon and incentivise crop diversity through strategic (and nutritious) cover crops, such as pigeonpea. Though rotation systems that use legumes and vegetables can increase rice yields in Africa, joint publicprivate sector strategies are needed to ensure quality legume seed production and distribution (Ojiewo et al. 2015).

After harvest, additional steps can be taken to reduce loss. Many nutritious foods (including fruit, vegetables, and dairy products) are perishable, therefore technology and good agricultural practices would increase the resilience of these value chains to climate shocks. Increased efficiency can also be achieved by providing storage and distribution infrastructure in value chains. This would also limit the impact of the production system on the environment, and vice versa (Gomez and Ricketts 2017).

Beyond adaption, opportunities also exist to introduce more nutritious crop varieties and increase uptake through location-specific interventions. The orange sweet potato from HarvestPlus and the International Potato Center (CIP) expanded to 14 sub-Saharan African countries through partnerships with Feed the Future and private companies, and exemplifies positive progress in interventions for nutritious foods. Indeed, by September 2016 orange sweet potato was estimated to have reached 2.89 million households (Low et al. 2017). However, the effectiveness of such interventions is dependent on consumer behavior and ultimately, consumer acceptance of the biofortified varieties. In the above example of the orange sweet potato, several consumer acceptance trials preceded large rollouts of specific varieties (e.g., Chowdhury et al. 2010). The importance of consumer behavior also extends to other nutritious crops; in Rwanda, the acceptance of high-iron beans was dependent upon location, income, and related nutritional information provided (Murekezi et al. 2017).

In addition, there are opportunities for public-private partnerships like the Feed the Future supported partnership in Ethiopia, to fortify wheat flour and provide iodised salt, with UNICEF and the Global Agriculture Information Network 
(Gillespie et al. 2017). The advantage of a value chain approach that incorporates the private sector is that, if profitable, entrepreneurs will have an incentive to further develop them, but a focus on both consumer and producer is necessary to target (and affect) malnutrition (Allen and de Brauw 2017). Partnerships between the public and private sectors have been developed to increase access to fortified foods, which can be especially important in rural areas (Gomez and Ricketts 2017). Understanding economic mechanisms behind consumer choices as well as how those may change as a result of climate change or variability will be necessary to ensure that activities targeting more nutritious crop production and consumption are sustainable.

\subsection{Implications for Development}

A growing body of evidence demonstrates that climate change will strain current agricultural production systems, with negative consequences for food security. However, the ramifications of climate change and increased yield variability on nutrition are not so well documented. The most nutritious crops may be less desirable for producers as they often require more inputs and need to be stored quickly after harvest to mitigate against spoilage.

Value chain interventions are an attractive option because they can overcome constraints on the use of inputs and support the development of transport and storage facilities for healthier products. As the climate continues to change, it will be increasingly important to strengthen nutrition-sensitive value chains so that producers have inputs, markets, and price incentives for these products.

These interventions will need to be tailored to the constraints and opportunities of specific regions, and attention must be paid to any environmental trade-offs that might be required. A number of nutrition-sensitive chains could provide resilience to climate change, including chains for biofortified crops and varieties (such as beans) that are more tolerant to heat and moisture stress.

As noted, it will be important to consider social and environmental trade-offs when evaluating the cost-effectiveness of value chain interventions and related programs, including capacity development infrastructure. Finally, public-private partnerships that strengthen market linkages can also be developed to improve the nutritious content of food and account for its environmental footprint.

\section{References}

Allen S, de Brauw A (2017) Nutrition sensitive value chains: theory, progress, and open questions. Global Food Security. In press. Available from: https://doi.org/10.1016/j.gfs.2017.07.002

Allen S, de Brauw A, Gelli A (2016) Nutrition and sustainability: harnessing value chains to improve food systems. In: International Food Policy Research Institute. 2016 Global Food Policy Report. International Food Policy Research Institute, Washington DC, p 49-56 
Baudron F, Chavarría JV, Remans R et al (2017) Indirect contributions of forests to dietary diversity in Southern Ethiopia. Ecol Soc 22(2):28. https://doi.org/10.5751/ES-09267-220228

Bouis HE, McClafferty B, Meenakshi JV et al (2011) Biofortification: a new tool to reduce micronutrient malnutrition. Food Nutr Bull 32:S31-S40 Available from: https://www.ncbi.nlm.nih. gov/pubmed/21717916

Chege C, Andesson C, Qaim M (2015) Impacts of supermarkets on farm household nutrition in Kenya. World Dev 72:394-407

Chowdhury S, Meenakshi JV, Tomlins KI et al (2010) Are consumers in developing countries willing to pay more for micronutrient-dense biofortified foods? Evidence from a field experiment in Uganda. Am J Agric Econ 93(1):83-97. https://doi.org/10.1093/ajae/aaq121

Davenport F, Grace K, Funk C et al (2017) Child health outcomes in sub-Saharan Africa: a comparison of changes in climate and socio-economic factors. Glob Environ Chang 46:72-87. https://doi.org/10.1016/j.gloenvcha.2017.04.009

De Brauw A, Eozenou P, Gilligan D et al (2015) Biofortification, crop adoption and health information: impact pathways in Mozambique and Uganda. HarvestPlus Working Paper \#21. Available from: http://ebrary.ifpri.org/cdm/ref/collection/p15738coll2/id/129795

Fanzo J, McLaren R, Davis C et al (2017) Climate change and variability: what are the risks for nutrition, diets, and food systems? IFPRI Discussion Paper 01645: International Food Policy Research Institute, Washington, DC. Available from: http://ebrary.ifpri.org/cdm/ref/collection/ p15738coll2/id/131228

FAO (2013) Climate-smart agriculture sourcebook. Food and Agriculture Organization of the United Nations (FAO), Rome. Available from: http://www.fao.org/docrep/018/i3325e/i3325e. pdf

FAO (2017) The state of food security and nutrition in the world: building resilience for peace and food security, Food and Agriculture Organization of the United Nations (FAO), Rome. Available from: http://www.fao.org/3/a-I7695e.pdf

Gelli A, Hawkes C, Donovan J et al (2015) Value chains and nutrition: a framework to support the identification, design and evaluation of interventions, IFPRI Discussion Paper 01413, International Food Policy Research Institute, Washington, DC. Available from: http://ebrary. ifpri.org/cdm/ref/collection/p15738coll2/id/128951

Gelli A, Margolies A, Santacroce M et al (2017) The NEEP-IE Study: rationale, design, and preliminary findings. Presentation at policy dialogue: improving food security, diets, and nutrition through multi-sectoral action: new evidence, challenges, and opportunities on 30 May 2017 in Lilongwe

Gillespie S, Van den Bold M, Stories of Change Study Team (2017) Stories of change in nutrition: an overview. Glob Food Sec 13:1-11. Available from. https://doi.org/10.1016/j.gfs.2017.02.004

GLOPAN (2015) Climate-smart food systems for enhanced nutrition. Policy Brief. Global Panel on Agriculture and Food Systems for Nutrition, London. Available from: https://glopan.org/ sites/default/files/pictures/GloPan\%20Climate\%20Brief\%20Final.pdf

Gomez M, Ricketts K (2017) Innovations in food distribution: food value chain transformations in developing countries and their implications for nutrition. In: Dutta S, Lanvin B, WunschVincent S (eds) The global innovation index. Cornell University, INSEAD, and WIPO, Ithaca

HarvestPlus (2017) Driving impact: harvest plus annual report 2016. HarvestPlus, Washington, DC. Available from: https://issuu.com/harvestplus/docs/harvestplus_annual_report_2016_fina

Hawkes C, Ruel MT (2012) Value chains for nutrition. In: Fan S, Pandya Lorch R (eds) Reshaping agriculture for nutrition and health. International Food Policy Research Institute, Washington, DC

Hirvonen K, Hoddinott J, Minten B et al (2017) Children's diets, nutrition knowledge, and access to markets. World Dev 95:303-315. Available from. https://doi.org/10.1016/j. worlddev.2017.02.031

Hotz C, Loechl C, de Brauw A et al (2012a) A large-scale intervention to introduce orange sweet potato in rural Mozambique increases vitamin A intakes among children and women. Br J Nutr 108(1):163-176. https://doi.org/10.1017/S0007114511005174 
Hotz C, Loechl C, Lubowa A et al (2012b) Introduction of beta-carotene-rich orange sweet potato in rural Uganda resulted in increased vitamin A intakes among children and women and improved vitamin A status among children. J Nutr 142(10):1871-1880. https://doi.org/10.3945/ jn.111.151829

IFPRI (2016) Global nutrition report 2016: from promise to impact: ending malnutrition by 2030. International Food Policy Research Institute, Washington, DC Available from: http://www.globalnutritionreport.org/the-report-2016/

AAA Initiative (2017) Addressing the challenges of climate change and food security, White Paper. The Initiative for the Adaptation of African Agriculture Climate Change. Available from: http:// www.aaainitiative.org/sites/aaainitiative.org/files/AAA_livre_blanc_ENG.pdf

Joshi PK, Rao PP (2017) Global pulses scenario: status and outlook. Ann N Y Acad Sci 1392(1):617. https://doi.org/10.1111/nyas.13298

Kabubo-Mariara J, Mulwa RM, DiFalco S (2016) The impact of climate change on food calorie production and nutritional poverty: evidence from Kenya. Environment for Development Discussion Paper Series 16-26. The Environment for Development (EfD) initiative. Available from: http://www.rff.org/files/document/file/EfD-DP-16-26.pdf

Katungi E, Magreta R, Letaa E et al (2017) Adoption and impact of improved bean varieties on food security in Malawi. CIAT-PABRA Research Technical Report. Pan Africa Bean Research Alliance, Cali. Available from: https://cgspace.cgiar.org/handle/10568/82725

Koppmair S, Kassie M, Qaim M (2016) Farm production, market access and dietary diversity in Malawi. Public Health Nutr 20(2):325-335

Lobell DB, Naylor RL, Field CB (2014) Food, energy, and climate connections in a global economy. In: Naylor R (ed) The evolving sphere of food security. Oxford, New York

Low JW, Mwanga RO, Andrade M et al (2017) Tackling vitamin A deficiency with biofortified sweet potato in sub-Saharan Africa. Glob Food Sec 14:23-30

Marlow HJ, Hayes WK, Soret S et al (2009) Diet and the environment: does what you eat matter? Am J Clin Nutr 89(S5):1699S-1703S

Murekezi A, Oparinde A, Birol E (2017) Consumer market segments for biofortified iron beans in Rwanda: evidence from a hedonic testing study. Food Policy 66:35-49

Myers SM, Smith MR, Guth S et al (2017) Climate change and global food systems: potential impacts on food security and undernutrition. Annu Rev Publ Health 38:259-277. Available from. https://doi.org/10.1146/annurev-publhealth-031816-044356

Nelson GC, Rosegrant MW, Palazzo A et al (2010) Food security, farming, and climate change to 2050: scenarios, results, policy options. International Food Policy Research Institute, Washington, DC

Ojiewo C, Keatinge DJDH, Hughes J et al (2015) The role of vegetables and legumes in assuring food, nutrition, and income security for vulnerable groups in Sub-Saharan Africa. World Med Health Policy 7(3):187-210. https://doi.org/10.1002/wmh3.148

Schreinemachers P, Sequeros T, Lukumay PJ (2017) International research on vegetable improvement in East and Southern Africa: adoption, impact and returns. Agricultural Economics. Available from: https://doi.org/10.1111/agec.12368

Shiferaw BA, Kebede TA, You L (2008) Technology adoption under seed access constraints and the economic impacts of improved pigeonpea varieties in Tanzania. Agric Econ 39(3):309323. https://doi.org/10.1111/j.1574-0862.2008.00335.x

Springmann M, Godfray HC, Rayner M et al (2016) Analysis and valuation of the health and climate change cobenefits of dietary change. Proc Natl Acad Sci USA 113:4146-4151. https:// doi.org/10.1073/pnas.1523119113

Stifel D, Minten B (2017) Market access, well-being, and nutrition: evidence from Ethiopia. World Dev 90:229-241

Taub DR, Miller B, Allen $\mathrm{H}$ (2008) Effects of elevated $\mathrm{CO}_{2}$ on the protein concentration of food crops: a meta-analysis. Glob Chang Biol 14:565-575

Vermeulen SJ, Campbell BM, Ingram JSI (2012) Climate change and food systems. Annu Rev Environ Resour 37:195-222 
WFP (2017) Home-grown school feeding: a framework to link school feeding with local agricultural production. World Food Programme, Rome Available from: http:// documents.wfp.org/stellent/groups/public/documents/newsroom/wfp204291. pdf?_ga=2.196122148.945026317.1507775688-1019979156.1507775688

World Economic Forum (2017) Shaping the Future of Global Food Systems. World Economic forum, Geneva Available from:https://www.weforum.org/whitepapers/ shaping-the-future-of-global-food-systems-a-scenarios-analysis

Open Access This chapter is licensed under the terms of the Creative Commons Attribution 4.0 International License (http://creativecommons.org/licenses/by/4.0/), which permits use, sharing, adaptation, distribution and reproduction in any medium or format, as long as you give appropriate credit to the original author(s) and the source, provide a link to the Creative Commons license and indicate if changes were made.

The images or other third party material in this chapter are included in the chapter's Creative Commons license, unless indicated otherwise in a credit line to the material. If material is not included in the chapter's Creative Commons license and your intended use is not permitted by statutory regulation or exceeds the permitted use, you will need to obtain permission directly from the copyright holder. 